\title{
Spectrophotometry and Electrochemistry of Brilliant Blue FCF in Aqueous Solution of $\mathrm{NaX}$
}

\author{
Bogdan Tutunaru*, Cristian Tigae*, Cezar Spînu, Ioana Prunaru \\ University of Craiova, Faculty of Sciences, Department of Chemistry, Calea Bucureşti 107i, Craiova, \\ România \\ "E-mail: tutunaruchim@yahoo.com, ctigae@yahoo.com
}

doi: $10.20964 / 2017.01 .64$

Received: 7 September 2016 / Accepted: 19 November 2016 / Published: 12 December 2016

The study of the electrochemical behaviour of Brilliant Blue FCF (BBfcf) food additive have been carried out by cyclic voltammetry on platinum electrode in aqueous solution of $0.1 \mathrm{~mol} \cdot \mathrm{L}^{-1} \mathrm{NaX}(\mathrm{X}=$ $\left.\mathrm{SO}_{4}^{2-}, \mathrm{F}^{-}, \mathrm{Cl}^{-}, \mathrm{Br}^{-}, \mathrm{I}^{-}\right)$. The effect of counter anion on the electrochemical behavior of BBfcf was also investigated by electrochemical impedance spectroscopy (EIS). Electrochemical degradation rate of coloring food dye under constant current electrolysis was determined in the presence of various counter anions by UV-Vis spectrophotometry and obeyed the following order: $\mathrm{I}^{-}<\mathrm{SO}_{4}^{2-}<\mathrm{F}^{-}<\mathrm{Cl}^{-}<$ $\mathrm{Br}^{-}$. Kinetic first order was successfully applied to the experimental results in order to calculate the constant rate and the half-time for the electrochemical degradation process. Based on experimental data the mechanism for complete electrochemical mineralization is proposed.

Keywords: E133 food additive, electrodegradation, active species, degradation mechanism

\section{FULL TEXT}

(C) 2017 The Authors. Published by ESG (www.electrochemsci.org). This article is an open access article distributed under the terms and conditions of the Creative Commons Attribution license (http://creativecommons.org/licenses/by/4.0/). 